\title{
TRAFFICKING OF WOMEN IN NIGERIA: CAUSES, CONSEQUENCES AND THE WAY FORWARD
}

\author{
LINUS AKOR ${ }^{1}$
}

\begin{abstract}
The phenomenon of the trafficking of women, especially of young girls and women into exploitative sexual and commercial labor, has recently begun to attract local, national and international attention from world leaders, academics, the mass media, advocacy groups, the clergy and humanity in general. This is against the back drop of the fact that the trafficking of women has a number of far-reaching socio-economic, health and political consequences. Several factors, among them poverty, unemployment, ignorance and family size have been implicated as being reasons why women fall easy preys to the antics of traffickers. From available statistics, we can say that about 500,000 women are brought into the United States of America and Europe yearly for sexual and domestic servitude. Of the over 70,000 African victims of women trafficking, Nigerian women account for 70 percent of those trafficked to Italy alone. Fighting the menace requires a coordinated and concerted push from all stakeholders. This paper presents the causes and consequences of the trafficking of women from Nigeria to America and Europe. Empirical evidence indicates that the activities of traffickers, corrupt embassy officials, the country's porous borders, poverty, refusal of victims to expose traffickers, delay in prosecuting apprehended culprits and biting youth unemployment have "conspired" to undermine the battle against the illicit trade. The paper makes far-reaching recommendations about how to mitigate the identified obstacles.
\end{abstract}

KEYwords The trafficking of women, poverty, prostitution, traffickers, Italo, madam

1 Linus Akor is lecturer at the Department of Sociology, Kogi State University, Anyigba, Nigeria. E-mail: linus_akor@yahoo.com. 


\section{INTRODUCTION}

The history of human trafficking, including that of the trafficking of women, cannot be completely divorced from the phenomenon of slavery. This is because both involve the acquisition and transportation of humans across local, national and international borders for servitude, with or without the consent of the trafficked person(s). Slavery, according to Oshadare (2004), is the social sanction of involuntary servitude imposed by one person or group upon another. He explains that slavery, as a phenomenon, made its appearance when pristine tribes reached the pastoral (as distinct from the hunting and gathering) stage of development. Slavery then was modest with regards to the number of slaves, because the care of flocks required only a few hands.

Omolola (1982) noted that a more dramatic change in the character and complexity of slavery came in the late 15-century and mid-19th century when many Africans were shipped across the Atlantic as slaves in what later became known as the trans- Atlantic slave trade. The intercontinental slave trade, which involved Europeans and Africans, was carried on through four continents of Europe, Africa and the two Americas.

Following the voyages countries such as Brazil and Haiti were discovered to be awash with rich mineral deposits and plantations waiting to be exploited. The exploitation of these resources required a large reservoir of labor, which the native Red Indians could not cope with. Consequently as more plantations were set- up and more mines were opened up, the demand for slaves increased dramatically and attention shifted to Africa. This marked the genesis of the massive importation of able-bodied Africans into the new world as slaves.

This trend in human trafficking for forced labor continued until 1808 when the obnoxious trade was formally abolished (Oshadare, 2004). Although slave trade ended in 1808 , nearly 200 years ago, a contemporary form of slavery, that of the trafficking in women and girls for exploitative sexual and commercial labor in Europe and America from Third world countries, particularly Africa, has been on the upward swing in recent years. Several socio-political, cultural and poverty related issues may have accounted for the phenomenon of the trafficking of women in Nigeria. Although acknowledged as the most populous black nation with boundless human and natural resources including being the sixth largest oil exporter, Nigeria, none-the-less ranks among the 20 poorest nations in the world. With an annual Gross Domestic Product (GDP) per capita estimated at $\$ 300,65$ percent of the country's population lives below the poverty line (UNICEF Report on, "Child Trafficking in Nigeria: Analysis of Nigeria's Response to the Libreville Platform of Action, " 2000). The United Nations Development Program, UNDP, (2005) citing a CIA World Fact 
book report, puts Nigeria's GDP per capita for 2005 at 1000 USD. Similarly, the UNDP's Human Development Report (2005) and the CIA World Fact book, estimated Nigeria's Human Development Index rating at 158 and 177, respectively.

The oil boom of the 1970s sparked a significant economic growth in the country with prospects for continued expansion. However, according to the UNICEF, by the end of the decade, Nigeria's economic growth had slowed due to the slump in world oil prices. The negative effects of the slump were worsened by prolonged military rule with the attendant mismanagement of the economy. The Federal Office of Statistics, FOS (1999) noted that the extreme human rights violations which characterized the period, led to international sanctions resulting in increased social tensions, inter-ethnic clashes, juvenile delinquency and children and women's rights abuses including biting unemployment.

According to the FOS (1999), since the rural areas were the hardest hit, mass migrations swelled the populations of major cities as parents and families began to take greater risks in an attempt to escape poverty and improve their living standards. Accepted practices such as placing and fostering children at the homes of relatives were turned into money-making ventures for parents and the phenomenon of cheap labour through human trafficking escalated, driving large numbers of young girls, women and children into the streets to work.

Trafficking of children and women for exploitative purposes in Nigeria is of two dimensions: internal and external. Internally, children are procured as domestic workers, while external trafficking provides girls and women for prostitution rackets in Europe and in some cases, unsuspecting young girls and women have fallen preys to traffickers who use them for rituals.

The inception of a democratic regime in Nigeria in 1999 seemed to have placed the issue of human rights, especially women and children's, on the front burner of national agenda with the government, individuals and civil society campaigning against the phenomenon of women trafficking. This study examines the causes and consequences of the trafficking of women in Nigeria with a view to proffering possible solutions to the menace.

\section{THE PROBLEM}

Admittedly, the trafficking of women with all its ramifications is tantamount to a debasement of womanhood. Given the dehumanizing treatment which trafficked persons receive, the phenomenon of the trafficking of women is 
beginning to attract attention from several quarters. The concern and attention which the menace of trafficking of women has begun to attract stems from the realization that the phenomenon, being a national and international crime, means that no one country or government has the power and the resources to eradicate it all alone.

No one can say with exactitude when the trafficking of women began, but the phenomenon can be said to have gained prominence in Nigeria in the early 1990s when drug trafficking and Advanced Fee Fraud (419) became commonplace. This probably explains why the American Drug Enforcement Agency, the International Police Organization (INTERPOL) and the National Drug Law Enforcement Agency, NDLEA, decided to collectively turn the heat on drug traffickers (Muhammed, 2004).

Eki Igbinedion, chairperson of Idia Renaissance, an NGO involved in the fight against the trafficking of women, argues that the trafficking of women began recently as an economic arrangement, a simple survival strategy adopted by families desperate for a reprieve from biting economic hardships (Muhammed, 2004).

Numerous factors such as poverty, level of ignorance and family size among other things account for why girls and women fall easy prey to the antics of traffickers. As it is well known, poverty is an inherent and factual reality especially in Africa. In Nigeria, the World Bank (1995) reported that over 45 per cent of the country's population lives below the poverty line.

Similarly, Chauhan (1978) observed the reality that in most poor homes parents can barely meet the legitimate needs of their children. He added rather painfully that the financial distress of most poor parents makes them vulnerable to the deceit of traffickers who promise their children juicy and supposedly rewarding jobs only to cajole them into prostitution and forced labor abroad. Saricho (1996) and Olayemi (1995) are of the view that a poor man can do anything possible to break away from the shackles of poverty including trading off their daughters to traffickers.

Beside poverty, many of the girls and women trafficked abroad are ignorant of the fate that await them in their country of destination. With little or no formal education some of the victims are easily carried away by the picture of Eldorado painted by their dubious sponsors. Adomako-Ampofo (1997) noted that many such victims have paid dearly for their ignorance while in Europe. Some scholars have also blamed trafficking on family size. One of scholar, Nye (1970) asserted that adolescents from larger families are more likely to feel neglected and rejected by their parents than those from smaller family backgrounds. He argued that rejected and neglected adolescents strive to find solace outside the home, thereby making them vulnerable to the tactics of 
traffickers.

Fighting the menace of the trafficking of women requires a co-coordinated and concerted push from all stakeholders. This probably explains why in Nigeria, there appears to be a collaborative effort between the government on the one hand and civil society, on the other hand, to nip female trafficking in the bud. Former President Olusegun Obasanjo openly decried the practice of the trafficking in women, which he said was disgraceful, and called for concerted efforts to rout it out of the Nigerian society (Rotimi, 2001). Underscoring the enormity of the problem of women trafficking in Nigeria, the then President lamented thus:

All over the world, our women are seen hawking themselves for a fee to the highest bidder like commodities. For us, who have seen this disgraceful way that our children are sold into slavery and prostitution any thing that can be done will be done to restore the dignity of Nigerian womanhood (Rotimi, 2001:6).

Part of the effort to eradicate human trafficking arising from the former President Obasanjo's pledge was the establishment of the National Agency for the Prohibition of the Trafficking in Persons, NAPTIP in August 2003 to investigate, prosecute and punish all offenders against the law of human trafficking in Nigeria (Olori, 2003). In spite of the well-meaning concerns such as those of former President Obasanjo and other stakeholders highlighted in this section of the paper, very few of the Nigerian women trafficked to Italy according to the International Organization for Migration (IOM, 1996) wish to return to their country of origin.

It is in view of these foregoing problems that the author seeks to x-ray the push and pull factors responsible for the seeming persistence of the trafficking of women in Nigeria in this paper. In doing this, we shall raise a number of questions such as: what are the causes of the trafficking of women, what are the mechanisms put in place by the government to check the menace, how effective are those mechanisms, why has the trafficking of women persisted despite the existence of legislation criminalizing the practice and what are the consequences of the trafficking of women?

As a corollary, the study will attempt to identify the causes of the trafficking of women in Nigeria; identify the mechanisms put in place to check the incidence of the trafficking of women; determine the effectiveness of those mechanisms; identify the factors accountable for the persistence of trafficking of women and determine the consequences of the illicit trade.

To put the discussion in proper perspective this paper is divided into several parts. After an introduction, a statement of the research problem, the theoretical 
framework and the methodology, part two deals with the clarification of concepts used in the presentation. These are the concepts of human trafficking, the trafficking of women, women traffickers, trafficked persons, internal trafficking and external trafficking. The third part of the paper discusses the broad issues of human trafficking and types; female trafficking across the world and trafficking of women in Nigeria while part four examines the causes of trafficking in women; methods and techniques of women traffickers and government's intervention in the fight against women trafficking. Part five discusses the consequences of the menace of women trafficking while the final part of the paper concludes with recommendations on measures to eliminate the monstrous activity of the trafficking of women in Nigeria.

\section{CONCEPTUAL CLARIFICATION}

The main concern of this section of the paper is to define the central concepts used in the paper to ensure clarity of conceptual usage. These terms, which are adapted from the legal instruments of Nigeria's National Agency for the Prohibition of Trafficking in Persons, NAPTIP (2003), are highlighted below.

\section{Human trafficking}

This involves the act and attempted act of recruitment and transportation of persons (both male and female) within or across borders.

\section{Women trafficking}

This refers to the recruitment and transportation of women across national or international borders either voluntarily or involuntarily, for sexual or domestic purposes. It also includes the purchase, sale, transfer, receipt or harboring of young girls and women through deception for the purpose of subjecting the women and girls to involuntary servitude. In this study, trafficking of women and female trafficking will be used interchangeably.

\section{Women Traffickers}

These are organized criminal rings involved in the smuggling (illegal transportation) of women across national borders to regional destinations (e.g. Europe and Italy). They are commonly referred to as "Trolley", "Italo" "Sponsors", "Madame" and "Boss", etc.

\section{Trafficked persons}

These are persons, male and female, recruited and transported within or across national borders for the purpose of sexual or domestic services. 


\section{Internal trafficking}

This is also referred to as domestic trafficking. It involves the recruitment and transportation of persons within the borders of a country, either from rural to urban areas or from one State to another, for purposes of sex work, child labor, or domestic services.

\section{External trafficking (Cross-border trafficking)}

External trafficking is also referred to as "international trafficking" and involves the movement of people across national, continental and international borders for the purpose of sex work, child labour and domestic service in exchange for monetary reward (Akor, 2007:7-8).

\section{THEORETICAL FRAMEWORK}

This paper is presented from a sociological perspective. Our theoretical framework is derived from the conflict area of study. A close look at Nigeria's social set up shows clearly that the capitalist nature of the economy has led to the polarization of the society into two diametrically antagonistic classes: the haves and the have-nots. What is more, the government's economic policies tend to favor the dominant capitalist class leaving the majority in dire straits. The collapse of the oil boom in the late 1970s and the imposition of the Structural Adjustment Program, SAP, at the insistence of the Breton Woods Institutions led to trying times for the majority of Nigerians. SAP has led to a decline in the purchasing power of the Naira and low capacity utilization of industries which in turn contributed to a decline in per capita income and a collapse of social services (Lipede, 2007).

Inequalities in rural and urban incomes widened overtime. Food insecurity, inability to meet basic needs like education, health care, etc., reflected the deepening poverty in rural communities. Flight to urban areas failed to bring the expected succor for job seekers as rising urban unemployment made job seeking a fruitless exercise. Poverty and a lack of opportunities to improve people's social conditions lead to a general loss of confidence in constituted authority and the subsequent rise in the rate of crimes such as armed robbery, prostitution, trafficking of women and drug trafficking, etc. Poverty manifested in illiteracy, unemployment and poor living standards occasioned by the failure of the government's socio-economic policies, therefore, appears to be at the heart of human trafficking. 


\section{Methodology}

Although much work has been done in the general area of human trafficking, there is a general paucity of data especially about the trafficking of women. This is mainly due as Lipede (2007) acknowledged, to the clandestine nature of the trade. This has compelled us to rely heavily on secondary literature sources such as reports, journals, books, newspapers, magazines and the internet for our data.

\section{HUMAN TRAFFICKING AND TYPES}

Human trafficking is a modern day slavery involving the movement of victims who are subject to violence, deception or coercion for the purpose of sexual exploitation or forced labor. The U.S Department of State (2004) estimates that 600,000 to 800,000 people are trafficked across international borders each year, while millions more are trafficked within their own countries. The International Labor Organization, ILO (2000) puts the number of children and women shipped across national boundaries and sold into modern day slavery at between 700,000 to 1000000 . According to the ILO, about 500,000 of these people are brought into the United States of America and Europe for sexual and domestic servitude.

Forte (2006) identified three major types of human trafficking. These are migrant smuggling, sex trafficking and labour trafficking. Migrant smuggling, according to him, is a form of trafficking in which smugglers assist migrants with their consent, to cross a national border, while sex trafficking is the trafficking in humans for the purpose of sexual exploitation. Victims of sex trafficking are forced into commercial sex industry-pornography, prostitution, stripping, livesex shows or illegal massage parlors or escort services (Forte, 2006). Still on the topic of sex trafficking, the U.S Department of State estimates that about 70 percent of all victims of international human trafficking are forced into the commercial sex industry, and half of all victims are children. With regard to labor trafficking, Forte said the practice is for the purpose of using humans for forced and indentured servitude such as maids, sweatshop factory hands, migrant agricultural workers or construction site laborers.

Trafficking of persons in Nigeria according to the Geneva-based United Nations International Children's Emergency Fund; UNICEF (1999) is of two types: internal and external trafficking. In internal trafficking children are procured by middlemen to serve as domestic and agricultural workers. In addition, because of the high level of poverty in the rural areas parents and 
families give their children to foster parents who engage these children in street hawking and domestic work.

External (international) trafficking provides girls and women for prostitution rackets in Europe and the Middle East. For the purpose of this research, our focus is on the external dimension of trafficking in persons. Criminal rings are involved in the smuggling of girls and women across national borders to regional destinations in Europe, particularly Italy where 60 percent of girl trafficking victims are Nigerians (UNICEF, 2000). The Fund estimated that more than 20,000 Nigerian girls are engaged in commercial sex work in Europe and most of the girls came from either Edo State or other states in the southeast regions of Nigeria. These are bad news for the country generally, and women in particular.

\section{Female Trafficking Across the World}

All over the world, it would appear that, governments have continued to allow female trafficking to flourish with near impunity. Lured with fraudulent and often unrealizable promises of lucrative opportunities, women migrate within and across national borders for work. A United States Department of State Trafficking Report released in 2000 found out that crime rings and loosely connected criminal networks traffic between 45, 000 and 50,000 women and children into the U.S annually (Hughes et al, 2005).

Brussa (1995) argues that in Milan, Italy, 80 percent of street prostitutes are foreigners, while according to the International Organization for Migration, (IOM, 1996), there are 19,000-25,000 foreign prostitutes in Italy, approximately 2,000 of who have been trafficked. The same source puts the age of victims of trafficking between 17-20 years with some "as young as 14 ". It also found out that the majority of the women and girls trafficked into Italy had not previously engaged in prostitution in their home countries.

According to the European Race Audit Bulletin No.25 (1997), trafficked and/or prostituted Polish women arrived (in Italy) around 1989; followed in 1992 by Nigerians and some Peruvians and Colombians. Between 60 to 80 percent of Nigerian girls/women in the sex trade outside the country are in Italy while Belgium and the Netherlands are experiencing an upsurge in the number of Nigerian girls (UNICEF, 2000).

\section{The trafficking of women in Nigeria}

Trafficked women from Nigeria predominantly go to Europe for prostitution, especially Italy, Spain, Belgium, France and the Netherlands. South Africa 
and the United states are also destination countries (Pearson, 2002). The United Kingdom and Ireland are countries of transit as well as destination countries. The Advocacy Project (N.D), reported that Nigerian women make up 70 per cent of 70,000 African victims of trafficking and that about 70 percent of these Nigerian women end up in Italy. According to Human Rights Watch (2001), Nigeria is a destination country for trafficked persons from Ghana, Togo, and Benin.

Hughes et al (2005), opine that hundreds of Nigerian women and girls, hoping to escape poverty and discrimination at home, voluntarily migrate to Europe and America in response to job offers as domestic workers or waitresses. However, upon arrival in their country of destination, many of these women discover to their dismay that it is not the much-expected "Eldorado" of their dreams, as the majority of them found themselves trapped in forced prostitution, saddled with exorbitant debts and compelled to work under brutal conditions.

Many of those who are trafficked to Europe for prostitution have tended to be of the Ibo tribe and from Edo and Delta States. There is no conclusive research on why women from these States are more likely to migrate but Pearson (2002:9) quoting the Task Force on Trafficking in Human Beings in Lagos, said, "Some Nigerians believe it is because the Ibo are especially enterprising and have a history of migrating". Adducing a possible reason for the predominance of women from Edo and Delta States among victims of trafficking, Pearson (2000) attributed the trend to poverty but added quickly that these States are not the poorest part of Nigeria.

Trafficking of girls and women from Nigeria is said to be especially well organized and centres on a female figure called "Mama" or "Madam", who plays a key role in luring young women to leave their homes for Italy. The trafficking web is organized at three levels; the first centers around "Mama" living in the country of origin; the second centers around the Nigerian "Mama" in Italy; and the third, the "Messengers" who are the persons who transfer the money from Italy to Nigeria (IOM, 1996). As part of the 'recruitment' drive, Nigerian girls are contracted in the suburbs of cities such as Lagos or Benin City and in the countryside in the south and east. As noted by Pearson, there has been a traditional migration flow from Nigeria to Italy since the late 1980s for agriculture, a trend he said, made many Nigerians to settle in Italy and other countries. He explained that it was predominantly these settled Nigerian women, often married to European men, who are traffickers/ madams. According to him, trafficked women are generally not aware of the conditions of work that awaited them (in Europe) i.e. confiscation of documents, forced to work long hours on the street every day, forced to serve 
a minimum of clients per day, physical abuse, threats and debt bondage. As revealed by the IOM (1996:12), "debts for travel are supposed to be paid off in six months but in the majority of cases, after three or four years, the girls are still in no position to pay back the debt they owe".

The Civil Liberties Organization, (CLO, 2000) noted that cartel or cartels behind the exportation of young girls and women overseas to work in the sex trade have largely remained faceless. No matter how many times the women might be deported; they seemed to be able to procure travel documents to return to the same or different foreign lands to continue in the illicit trade. While some entered the trade knowingly- sometimes with the connivance, approval or acquiescence of their parents - others appeared to have been lured into it with false tales of money to be made from plaiting or weaving hair, or working as maids or children's nannies- tales which though false, could seem reasonable to young women anxious to help reduce the hardship being faced by their families (CLO, 2000).

According to the CLO (2000), once it becomes established, the trafficking business is extremely difficult to eradicate due to the number of other 'small enterprises' which depend on it and service it. These include forgers, disreputable and even fake lawyers who set up "contacts" between the girls and the traffickers, self-styled "evangelists" who pray for them, traditional voodooists who hold the victims to their promises or undertakings, Customs and Immigration officials who receive bribes to look the other way when regular streams of young women with no visible support are escorted out of the country, and in some cases, corrupt embassy officials who facilitate the issuance of visas.

As the illegal trade in women continues to boom, a large number of Nigerian girls and women have over the years been repatriated from Europe and elsewhere with dire consequences for both the victims and the country's international image. A Newswatch magazine report between March 1999 and 2000, cited by the CLO (2000), revealed that 287 Nigerian girls who were trafficked to Italy and Saudi-Arabia for prostitution were deported. A breakdown of the year 2000 figures showed that 17 women were deported from Saudi-Arabia, 76 from Italy while 200 others were sent packing from the Netherlands.

Although the figures of those deported hardly gives a true picture of the number of girls and women being trafficked, a report by WOCON (2000) is very revealing indeed. WOCON reported that between March 23 and July 19, 2000, a total of 247 girls and women whose ages ranged from 18 to 38 were deported from Italy, Saudi-Arabia, Holland, South Africa, Togo and Mali to Nigeria. Of this number, 163 were from Italy, 17 from Saudi-Arabia, 2 from 
South Africa, 41 from Togo while 4 came from Mali. According to the report, 162 deportees were from Edo State (the highest number of deportees), adding that 26 of the returnees tested positive for the Human Immune Virus/Acquired Deficiency Syndrome, HIV/AIDS.

Ojomo (2000) on the other hand, reported that more than 500 Nigerian prostitutes were rounded up in Italy between 1999 and 2000 and deported to Nigeria at very short notice. According to him "the first mass deportation of Nigerian women from Italy came as a nasty surprise to the Nigerian authorities" (Ojomo, 2000:15).

Although more than 90 percent of the girls and women trafficked from Nigeria are believed to come from the southern part of the country with Edo State leading ( with $90 \%$ ) followed by Delta (5\%) and the rest of the country trailing with $5 \%$, human trafficking in the northern part of the country is believed to be growing (Lipede, 2007). According to Lipede, "of the 20,383 trafficked women victims were deported from the Kingdom of Saudi Arabia between March 2002 and April 2004, 9,952, were found to have come from Kano, Borno, Yobe, Nasarawa, Plateau, Niger, Kwara, Sokoto, Katsina, amfara, jigawa, Kaduna, Gombe, Bauchi and Taraba States" (Lipede, 2007:16).

Commenting on the lack of commitment to the eradication of the phenomenon by the Nigerian authorities, the CLO (2000:179) posited that Nigeria does not seem any closer to any serious attempt by its law enforcement and social agencies to bring those behind the trade in women and girls to justice as "the country still seems to be at the stage of becoming aware of the dimensions of the problem and documenting it."

The CLO's position appears at variance with the situation on ground as both private and public initiatives have been started to bring traffickers to book through the promulgation of the WOTCLEF and NAPTIP bills in 2003, which criminalize human trafficking, including the trafficking of women in Nigeria.

\section{CAUSES OF THE TRAFFICKING IN WOMEN}

The traffic in humans, especially women, appears to be flourishing. The global business involving "human goods" seems to have attained a level comparable to those of the illicit trades in drugs and weapons. In terms of numbers, the major victims are women and children who are forced into prostitution or forced labor.

Two main reasons which are commonly referred to as 'Push and Pull' factors may be accountable for the prevalence of trafficking in women. These 
reasons as outlined and elaborated by Pearson (2003), include, firstly, harsh living conditions mostly characterized by poverty, unemployment, and a lack of opportunities in the countries of origin and, secondly, the demand that exists in the rich countries of the West. Pearson explained further that it is under such circumstances that the victims are exploited as cheap labor in the restaurant trade or the sex industry through forced marriage and illegal adoption. Simply put, these are the push and pull factors.

For Anita (2000), some of the trafficked women chose to migrate for sex work because of the realization that the sex trade is profitable. Scripraphai and Scripraphai (1997), on the other hand, maintained that the trade in human beings is an outgrowth of international labor migration. In their view, people seek to migrate temporarily to work in richer countries in order to improve their economic standing at home. The duo explained that while job opportunities abound for male migrants in Europe and North America, women migrants who had no access to jobs often take to prostitution as an option.

Apart from the economic factor, there are some people who blame the trafficking of women on the fact that women in Third world countries are held in low esteem and consequently manipulated and controlled by a maledominated society. One such person is Jane Edeki of the African Women Empowerment Group (AWEG), a non- governmental advocacy group based in Nigeria. Edeki asserted that if women were empowered by the maledominated society, they would be hard put to let themselves be trafficked (Oshadare, 2004).

Edeki's view appears subjective because even in the advanced societies of the West, gender inequality abounds. Therefore, inequality in terms of gender empowerment cannot be enough of a driver.

An added causative factor behind the trafficking in women is the total absence, in some cases, of legislation criminalizing the practice as well as the non-enforcement of such legislation in countries where it exists. A seminal study conducted by Hughes et al (2005), on this factor in Japan, and Bosnia and Herzegovina and Israel is very revealing. Hughes et al (2005), reported that although the Israeli Knesset (Parliament) amended the criminal code to make the buying and selling of human beings for prostitution a criminal offense, the law had little impact as trafficked women were not treated as victims but as criminals and illegal aliens. The law had little effect on traffickers who continued to bring in hundreds of women and girls from the countries of the former Soviet Union and Eastern Europe into Israel for forced labour in the sex industry.

As in Israel, the Japanese government also did not do enough to give its law criminalizing the trafficking in women, the desired teeth. Hughes et al (2005) 
observed that although the Japanese government identified an amendment to the law on control and improvement of Amusement Business to address trafficking, the law was inadequate because it lacked criminal penalties.

The absence of a definite law against the illicit trade in women in Bosnia and Herzegovina may have provided a launch pad for traffickers to abuse and exploit women from the former Soviet Union and Europe with impunity. Hughes et al (2005) submitted that interviews with Human Rights Watch revealed that women trafficked from Ukraine, Moldova, and Bulgaria into Bosnia reported being sold from one brothel owner to another as well as being placed in debt bondage as well as being threatened and actually beaten.

In summary, the major causes behind the trafficking of women are widespread poverty which sparks off the push-pull factors, a high level of illiteracy, unemployment and poor living standards as well as burdens of poverty of and desperation of poor and illiterate parents with large families who are ignorant of the impacts or nature of child trafficking (UNICEF, 2000).

\section{Methods and Techniques of Traffickers}

There is usually a symbiotic relationship between the trafficked woman and her traffickers according to the International Organization for Migration, (IOM, 1996). Traffickers are often young criminals attracted by the prospect of making easy money. According to the above source, Albanian women and girls trafficked into Italy are usually recruited informally by friends and relatives as well as through organized and independent groups operating on a small scale.

Traffickers use the same migration routes and methods that are generally used for illegal migration. In Albania for example, they use fishing boats to the limits of territorial waters and small boats to the Italian coast route or the coast route along the eastern Adriatic coast northwards; with the total cost of the journey being around 2800 to 5000 dollars, depending according to IOM (1996), on the route and the expected difficulties.

UNICEF (2000) reported that the trafficking of Nigerian girls and women to Italy and other parts of Europe has slave-like characteristics, a trend it attributed to the tightening of controls on illegal immigration to Europe. The UNICEF painted a graphic picture of the tortuous journey thus:

Many Nigerian girls and women are obliged to take long routes across the Sahara to North Africa and make the hazardous journey across the Mediterranean in small boats. Several of them never 
reach their destinations either because they are abandoned enroute or they drown. Those that reach their destinations are sold off to prostitution rackets and or engage in other forms of commercial sex work (UNICEF, 2000).

In spite of the hardships which trafficked women go through either on their way to Europe or the dehumanizing treatment they receive in the hands of the traffickers and their agents, only very few of the Nigerian women in the sex trade in Italy wish to return to Nigeria. IOM (1996) blamed this seeming reluctance on what some of the women said were lack of better alternatives to prostitution in Nigeria, fear of reprisals from the traffickers and the shame and stigma of returning home without being successful abroad.

\section{Nigerian Government's Intervention in the Trafficking of women}

Worried by the menace of the trafficking of women and its concomitant negative image on the country, the then President Olusegun Obasanjo administration adopted a three-prong attack against the monstrous trade. At the level of the Presidency, was the National Agency for the Prohibition of Trafficking in Persons and other Related Matters (NAPTIP). Secondly, there were the federal government paramilitary agencies such as the Nigeria Immigration Service, (NIS); the Nigeria Police (NPF) and the Nigerian Customs Service (NCS). The third prong was at the level of government parastatals like the National Emergency Management Agency (NEMA), whose primary assignments are only indirectly related to human trafficking (Lipede, 2007). We shall only concern ourselves with the activities NAPTIP in this study.

To give legal teeth to the attack on human trafficking in Nigeria, the Federal Government sent a bill to the National Assembly seeking to outlaw human trafficking. The bill, which was passed in August 2003, established the National Agency for the Prohibition of Trafficking in Persons, NAPTIP, which formally criminalized human trafficking. According to its mission statement, NAPTIP is committed to the prevention of all forms of human degradation and exploitation through the coordinated use of Nigeria's crime prevention and law enforcement resources (Daily Independent Advertorial, 2005).

The agency's act prescribes punishments ranging from 10 years to life imprisonment for traffickers caught exporting persons out of Nigeria and importation of the same into Nigeria plus the procurement of any person for illicit intercourse with another person (Daily Independent Advertorial, 2005). 
In executing its mandate, the agency has been able to take the anti-trafficking battle to the grass roots level in a number of States and Local Government areas in the country through imaginative posters, enlightenment campaigns, radio and television jingles as well as seminars and workshops. The agency has, through its legal and prosecution unit established an investigation task force made up of representatives of the Nigeria Police Force, the Nigeria Immigration Service, National Intelligence Agency and the judiciary. The task force has a total staff strength of 69 , including 40 new members of staff. All of them have gone through induction courses, 10 of them at the Police Detective School in Enugu (NAPTIP 2003).

Working in close collaboration with other agencies, NAPTIP's investigation unit, according to Lipede, (2007) was able to prosecute and convict one trafficker named Sarah Okoma, who was tried in Benin and sentenced to three years imprisonment in November 2004. Between 6 May and June 2004, 32 cases concerning the trafficking of women were referred to NAPTIP from the headquarters of the Nigerian Immigration Service. Out of the other 41 cases reported to NAPTIP in 2004, 27 have been interrogated and eight of them arraigned in courts in Auchi, Benin, Uromi, Kano, Ilaro and Ibadan. Six new cases were reported to the NAPTIP in 2005 (Lipede, 2007). The Agency is currently pressing charges against Alhaji Sani Yerima, former Governor of Zamfara State and serving Senator of the Federal Republic of Nigeria for marrying a 13 year Egyptian minor in contravention of the NAPTIP act.

Attempting to get to the source of voodoo priests who make it difficult for victims to provide information about traffickers, the agency raided two juju shrines in Edo state, arrested the priests and confiscated their charms and other items including photographs of trafficked victims. In collaboration with the anti-human trafficking units and other security agencies, NAPTIP has successfully intercepted teams of traffickers and their victims within Nigeria and across the Sahara Desert (NAPTIP, 2003).

Babandede (2004) explained that even though the NAPTIP does not provide micro credit schemes, it works closely with relevant federal government poverty alleviation agencies such as the National Directorate of Employment, NDE, or the National Program for the Eradication of Poverty, NAPEP, to ensure that rehabilitated female victims of trafficking can access funds to set up shop, while the rehabilitation division of NAPTIP collaborates with anti-human trafficking units of the Immigration Service as well as local and international NGOs to rehabilitate and reintegrate victims of human trafficking. Evident in NAPTIP's collaboration with the International Organization for Migration, (IOM) and ALNIMA (an NGO), was the successful rehabilitation of 18 repatriated victims and the reuniting of 14 with their families. 
NAPTIP has also been active in the area of cooperation and collaboration with a number of countries both within the West African sub-region and in other parts of the world. This is particularly so with source, transit and destination countries. The agency has in place a Memorandum of Understanding (MoU), with England and Northern Ireland. In May 2004 the agency signed a memorandum of agreement with the Italian government while the kingdoms of Saudi Arabia, Spain and the Netherlands have been cooperating in the areas of intelligence sharing and prosecution. The recent submission of the names of traffickers with their addresses to Interpol for investigation is an example of the useful cooperation on going between Nigeria and Spain (Babandede, 2004). Despite the three-prong approach adopted by NAPTIP to nip the trafficking of women in the bud, the business is extremely difficult to eradicate due to the number of other 'small enterprises' which depend on it and service it. These include forgers, disreputable and even fake lawyers who set up "contacts" between the girls and the traffickers, self-styled "evangelists" who pray for them, traditional voodooists who hold the victims to their promises or undertakings, Customs and Immigration officials who receive bribes to look the other way when regular streams of young women with no visible support are escorted out of the country, and in some cases, corrupt embassy officials who facilitate the issuance of visas.

\section{CONSEQUENCES OF THE TRAFFICKING OF WOMEN}

Trafficking in women is a global problem affecting large numbers of girls and women. It is lucrative and is linked with criminal activity and corruption, as it is often hidden and hard to address. As pointed out by IOM (1996), women who have been trafficked face a range of dangers, including violence and sexual abuse. In some cases, trafficked women encounter State complicity as they are arrested and detained as illegal aliens.

Brussa (1996) remarked that women's physical and mental well being is harmed by the isolation they suffer by being confined in closed apartments and the restriction of their movements.

In addition to the consequences of the trafficking of women highlighted above, there is also the more worrisome health dimension. Jane Edeki of the African Women Empowerment Group (AWEG) warns that the trafficking of women poses a mortal danger to Nigerian women because of the high incidence of Human Immune Virus/Acquired Deficiency Syndrome HIV/ AIDS infection among deported Nigerian girls and women (Oshadare, 2004). In fact, in many rural Nigerian villages and even urban centers, it is 
common to find young women and girls who were sold into prostitution in Italy and elsewhere and who had contracted AIDS abandoned to their fate. Beyond the women victims of HIV and AIDs are orphans. In 2003, 26\% of all orphans were orphaned due to AIDS. (UNAIDS, UNICEF, USAID,, 2004). Consequently, most of these children left on their own are easily recruited by traffickers. A vicious circle thus ensues: HIV and AIDS prevalence increases the number of orphans trafficked as illustrated in case of the AIDS orphans. Simultaneously, trafficking increases the number of HIV infections.

In general, women and girls are more vulnerable to HIV and AIDs infection, thus trafficked girls and women are most at risk. In the case of those trafficked for purposes of commercial sex work, Burkhalter (2003) explained that vulnerability is increased in a variety of ways:

Trafficked persons are unable to insist upon condom use. Trafficked persons may be forced to perform those sexual practices most associated with AIDS transmission. Trafficked persons are forced to have sex with multiple partners. Violence in commercial sex is common; especially where women or children are forced to have sex against their will .Injuries sustained during forced sex may increase vulnerability to HIV transmission. The physically immature bodies of young girls are extremely vulnerable to sexual injury. Such injuries increase their risk of infection. Many trafficked persons have other sexually transmitted diseases (STDs) due to forced and unsafe sexual activities. This heightens the risk of contracting HIV by up to a factor of 10 (in UNESCO, 2006:40).

UNICEF (2000) summarized the consequences of trafficking in girls and women from Nigeria to include loss of lives, increasing prevalence of sexually transmitted diseases including HIV/AIDS, increase in violence and crime rate, increased school drop-out rates, impaired child development, poor national image and massive deportation of Nigerian girls and women.

\section{ICT AND ILLEGAL HUMAN TRAFFICKING}

The introduction, growth, and utilization of information and communication technologies (ICTs) have been accompanied by an increase in illegal exploitation and abuse of technology for criminal activities. Although new techniques are constantly being implemented and regulations being adopted to combat and eradicate diverse forms of human trafficking, ICTs are also providing new means and tools that facilitate human trafficking especially for 
sexual exploitation. According to Chawki and Wahab (2005), the use of ICTs in human trafficking involves the utilization of computers and/ or networks. The duo in a study commissioned by the Computer Crimes Research Center identified the fact that users in ICT-supported trafficking included collectors of child pornography, stalkers and buyers.

According to them, some of the distributors of pornography on the internet started off as collectors and then decided to profit from their collections while other sex offenders such as pedophiles engage children on many levels, from sexual talk to enticing them into physical contact. They added that there are also those who buy women and children for the purpose of sexual exploitation. Explaining how collectors of pornographic materials operate using the ICTs, Chawki and Wahab noted that:

Acquiring a computer and accessing the internetenables the traffickers to get satisfaction from images and fantasy and meet a virtual community of people who reinforce their behavior. They may develop a sense of confidence in themselves for their new computer skills and success at building a large collection. Most start out accessing adult pornography, and then move on to child pornography. They continually move up to more sophisticated technologies and more extreme forms of sexual exploitation of children, either seeking more harmful, extreme images, or the physical sexual abuse of children. Collecting these materials is an important psychological process and is directly connected to acquiring new technological skills. The offender becomes increasingly "empowered" by the combination of a physical collection, sexual satisfaction, computer skills and a supportive online community (Chawki and Wahab, 2005:3)

In the view of Chawki and Wahab, the internet has also become a favored site for stalking children, noting that sex offenders engage children on many levels from sexual chat to enticing them into physical contact.

\section{FINDINGS, CONCLUSION AND WAY FORWARD}

This study examined the causes and consequences of the trafficking of women from Nigeria to America and Europe with a view to identifying the push and pull factors responsible for the persistence of this modern day slavery. The study posed a number of questions, among them; what are the causes of human trafficking, what are the mechanisms put in place to stem the tide of the trafficking of women, how effective are these mechanisms 
and why has the trafficking of women persisted despite the existence of laws criminalizing the illicit business? One of the major findings of the study is that poverty is largely responsible for the migration of Nigerian girls and women for prostitution abroad. From the study it was discovered that there is little prospect of the menace of the trafficking of women being eliminated from Nigeria in the nearest future unless the specters of poverty, unemployment and all the other push and pull factors are adequately addressed.

From the study it was discovered that contrary to the picture of paradise painted about Europe and America by the traffickers, the trafficking of women victims were exposed to and indeed, partook of such degrading works as house maids, nannies, hair platters and eventually engaged in prostitution while abroad. Another finding from the study attributes the persistence of the trafficking of women in Nigeria to the country's porous borders, activities of traffickers and some corrupt embassy officials who issue visas to traffickers and their prey. Also revealed by the study is the fact that the absence of specific legislation which criminalized the trafficking of women in Nigeria prior to 2003 has direct a direct bearing on the prevalence of cases of the trafficking of women in the country. Arising from the above, the following recommendations are made to stem the tide of the trafficking of women in Nigeria:

1. From available literature evidence, poverty, grinding unemployment and widening inequalities are the major push factors in the incidence of cases of the trafficking of women in Nigeria. Concerted efforts must be made to address the root causes of the trafficking of women, which among others are poverty and unemployment. Girls and women are more vulnerable to the false promises of traffickers when they are poor and see very little prospects of moving out of their state of deprivation.

2. Since women are more vulnerable to trafficking, a social security policy should be put in place to enhance their access to education by providing them with scholarships. This has the added advantage of making the millennium development goals of ensuring rights for girls and child education acts more reachable. The policy should also aim at efforts to improve the low status of women, particularly at dispelling the economic disadvantages they face.

3. There is an urgent need to develop facilities and social services for the reception, protection and reintegration of trafficked persons to prevent as much as possible the re-trafficking of once trafficked people.

4. It is also important to develop awareness raising and educational courses about HIV and AIDS and human trafficking to better inform the public about the mutually reinforcing effects of these two phenomena. 


\section{REFERENCES}

Adomoko-Ampofo, A. (1997), "To be or not to be a Prostitute: The example of Ghanaian Prostitutes in Netherlands", Institute of African Studies, University of Ghana.

The Advocacy Project Nigeria (N.D), available at

http://www.advocacynet.org/cpage_view/wocon_18-26. html. Retrieved 05/05/2010

Akor, L. (2007), Women Trafficking in Nigeria: A Study of the Women Trafficking and Child Labor Eradication Foundation, WOTCLEF, Abuja; Unpublished M.Sc. thesis, University of Nigeria Nsukka: UNN Library.

Babandede, M. (2003), "NAPTIP - Effort in Combating TIP, Specially in Rehabilitation" Paper presented at a Workshop organized by TAMPEP.

Brussa, L. (1995), "Trafficking of Women to the European Nations: Characteristics, Trends and Policy Issues" European Conference on Trafficking in Women, U.K.

Carney, L. P. (1977), Probation and Parole: Legal and Social dimensions, New York Graw-Hill Book Company.

Chauhan, S.S.(1978), Polices and Programmes for Social and Human Development, A Handbook produced by the United Nations World Summit for Social Development, San Francisco International Centre for Economic Growth.

CLO (2000), Report on the State of Human Rights in Nigeria, published by the Civil Liberties Organization, Lagos Daily Independent Advertorial (2005) A 10, Friday, October 7.

European Race Audit Bulletin No. 25, (1997). The Institute of Race Relations, London U.K.

Forte, V.L. (2006), Types of Human Trafficking, Minerva Webworks, available at http://www.bellaonline.com/articles. Retrieved 18/06/2010

FOS (1999), Poverty Profile for Nigeria, 1980-1996, published by the Federal Office of Statistics, Lagos.

Hughes, M.D, Sporcic, L.J, Mendelson, N.Z, and Chirgwin, V. (2005), “Coalition Against Trafficking in Women" Fact book on Global Sexual Exploitation, available at www.catwpage.net..s. Retrieved 16/06/2010.

Human Rights Watch (2001). http://www.hrw.org/press 2001/07/trafficking-0712. html http://www.wotclef.net-aboutus:5. Retrieved 21/06/2010

ILO (2000), "Child Trafficking in Nigeria-The State of the Act", published by ILO/ IPEC.

IOM(1996), "Trafficking in Women for Sexual Exploitation to Italy" Migrant Information Organization.

Lipede, A. (2007), "Women Trafficking and Insecurity in West Africa: Character, Trend and Scale in Nigeria" in Barkindo, B.M and A. Lipede (ed.) Human Trafficking and Economic Crimes across Nigeria's International Borders, Ibadan: Spectrum Books Limited. PP.3 - 43.

Muhammed, R.E. (2004), The Role of a Non- Governmental Organization in the Prevention of Women Trafficking in Benin City, Nigeria, Unpublished B.Sc. 
degree Thesis, Anyigba: Kogi State University, Library.

Ojomo, A, J. (2000), "Child Trafficking in Nigeria: Policy Perspectives". A paper presented at the FMWA \& YD/ UNICEF Conference on Child Trafficking, Benin, Nigeria.

Okolocha, F.O., Nwanuobi, C.O. \& Igbo, E.U.M. (1999) Introductory Sociology Lagos: Acquitas Consortium.

Olayemi, J.K. (1995), “A Survey of Approaches to Poverty Alleviation" Paper presented at the NCEMA National Workshop on Integration of Poverty Alleviation Strategies into Plans and Programmes in Nigeria, Ibadan, November 27-December 4.

Omolola, I.(1982). Main Trends in African History from the Earliest Times to $\quad 1900$, Omolayi Standard Press Co.

Oshadare,O.T. (2004). "The Past and Present Dimensions of Slavery in Nigeria" Paper presented at the First National Conference of the Faculty of Arts and Humanities, held at the Kogi State University, Anyigba from 28th - 30th April.

NAPTIP (2003), Act establishing the National Agency for the Prohibition of Trafficking in Persons and Other Related Matters.

Nye, F.I. (1970), "Child Adjustment in Broken and Unhappy Homes" Journal of African Marriage and Family Living, 19.

Olori, T. (2003), "Nigeria: Life Sentence for Human Trafficking” Inter Press Service from http:// www. Africa.no/Detailed/3866. Retrieved 15/07/2010

Pearson, E. (2002). "Human Traffic, Human Rights: Redefining Victims' Protection" Anti- Slavery International, London.

Pearson, E. (2003), "Sector Project against Trafficking in Women" available at http:// www.gt/ trafficking in women. Retrieved 18/07/2010.

Rotimi, A. (2001), “Obasanjo decries Women trafficking”, National Newsreel, 6-12.

Saricho, A. (1996), Policies and programmes for Social and Human Development, A Hand book produced by the United Nations' World Summit for Social Development, San Francisco Centre for Economic Growth.

Scripraphai, I. and Scripraphai, B. (1997), The Traffic in Women: Human Realities of the International Sex Trade, New York.

Ted, I. (2001), "Titi Abubakar flags off campaign Against Women trafficking”, The Guardian, 1-3

UNICEF, (1999), "Child Trafficking in Nigerian Southern Border Towns" in Child Rights Monitor, Vol. 1, No. Pp. 55-63.

UNICEF (2000), "Child Trafficking in Nigeria: Analysis of Nigeria's Response to the Libreville Platform of Action" - Joint initiative between the UNICEF West and Central African Regional Office and UNICEF Nigeria Country Office.

Women's Consortium of Nigeria, WOCON (2000), Research on "Trafficking in Women in Nigeria" supported by the Netherlands Embassy, Lagos. World Bank (1995), Advancing Social Development, the International Bank for Reconstruction and Development, Washington D.C. 